\title{
The Gametophyte and Embryo of Botrychium simplex, Hitchcock.
}

\author{
BY
}

\section{DOUGLAS H. CAMPBELL.}

\section{With Plate XVI and ten Figures in the Text.}

ROTRYCHIUM SIMPLEX, Hitchcock, is the smallest species of the genus, and is reported from various stations in northern Europe, Japan, and North America, ${ }^{1}$ being decidedly a boreal species. In some of its forms it shows a striking superficial resemblance to a small Ophioglossum, while the larger forms are much like $B$. lunaria, to which it is undoubtedly not very remotely related. There seems to be no doubt, however, that it is a valid species.

Luerssen ${ }^{2}$ figures a very interesting series of forms, but thinks that these represent, to a great extent, only different ages. The second leaf of the young sporophyte, although very small, nevertheless is fertile, and it is probably several years before the sporophylls reach their full development. Text-fig. I shows two extremes found by the writer in a number of specimens collected by Dr. H. C. Lyon, to whom the writer is indebted not only for these specimens, but also for the material of the gametophyte and young sporophytes upon which the present paper is based.

Dr. Lyon has sent the writer the following account of the conditions under which the material was collected in Minnesota:

' My material of Botrychium obliquum and of B. simplex was collected in swampy ground on the shores of Echo Lake. This is a small lake a few miles from White Bear Lake. The soil in this district is mostly sand and carries a sparse forest of white oak, bur oak, red oak, black oak, birch and poplar. All three species of Osmunda occurred here in great abundance. Lycopodium obscurum and $L$. inundatum occur here, while the only known station of Ophioglossum vulgatum in this state is at this point. I collected Botrychium matricariaefolium gametophytes only a few rods from the point where those of $B$. simplex were found. Isoetes occurs abundantly in the shallow water of Echo Lake. You will note from the above that this region

1 Christensen, C. : Index Filicum, 1906.

2 Luerssen, C.: Die Farnpflanzen oder Gefässkryptogamen, Fig. I 81, Leipzig, I889.

[Annals of Botany, Vol. XXXVI. No. CXLIV. October, 1922.] 
carries a remarkable Pteridophytic flora. It is also remarkable in that many of the flowering plants of the northern woods occur here. The orchid flora is particularly rich and interesting.'

The gametophyte of $B$. simplex is much like that of the other species that have been described, ${ }^{1}$ being on the whole most like that of $B$. lunaria,

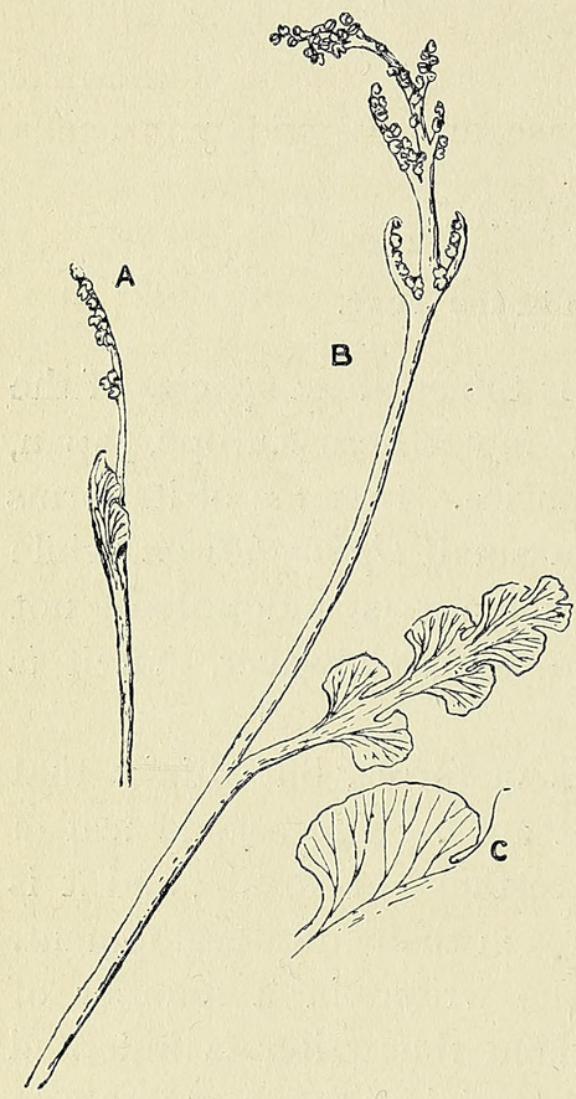

TEXT-FIG. I. A, B. Two specimens of Botrychium simplex, Hitchcock, collected by Dr. H. L. Lyon at Echo Lake, Minnesota. Natural size. C. Leaf segment showing venation. $\times 3$. as might be expected. Bruchmann describes the latter as a small subterranean tuber-like body, 1-2 millimetres in length. In all these respects $B$. simplex agrees closely with B. lunaria, except that some of the specimens examined by the writer were slightly larger than the dimensions given for $B$. lunaria, reaching a maximum length of about three millimetres. Bruchmann shows figures of several cases where there apparently had been a dichotomy of the apex of the gametophyte, which had two short divergent branches, so that the gametophyte was heart-shaped. This condition was not seen in $B$. simplex, but it is quite possible that it may occur.

In both B. simplex and B. lunaria, which belong to the section Eubotrychium, the gametophyte is much smaller than in either B. obliquim or B. virginianum, representing respectively the sections Sceptridium and Osmundopteris. ${ }^{2}$

Fig. I of Plate XVI shows one of the youngest specimens found in the material examined. Seen from above it is nearly oval in outline, slightly pointed at the apex, which is nearly colourless, while the older portions are brownish in colour. Short dark-brown rhizoids are present, but these are neither so abundant nor so long as Bruchmann figures for $B$. lunaria. These rhizoids are still less conspicuous in older stages, such as that shown in Fig. 2.

As in the other species of Botrychium the gametophyte is decidedly dorsiventral in structure, somewhat flattened, and with a more or less conspicuous median ridge upon which the antheridia are borne. The latter begin to develop when the gametophyte is very small, and new ones arise in

1 Bruchmann : Über das Protballium und die Sporenpflanze von Botrychium lunaria, L. Flora, 1906: Jeffrey, E. C. : The Gametophyte of Botrychium virginianum. Proc. Canad. Inst., I898, 5 ; Campbell : The Eusporangiatae. Carnegie Institution of Washington, Publication No. I40, I9I I.

2 Campbell, Gametophyte and Embryo of Botrychium obliquum, Mïhl. Ann. of Bot., xxxv. I 57, I92 I. 
acropetal succession for a long time. While the archegonia are somewhat later in making their appearance, still the first ones are formed while the gametophyte is still very young. They do not develop upon the median ridge, but form a line on either side of it (Plate XVI, Figs. I, 2, 5, 6).

Sections of the gametophyte (Figs. 3, 5) show it to be composed of nearly uniform parenchyma, which in the older portions of the thallus is infested with the characteristic endophytic fungus found in all the Ophioglossaceae. In $B$. simplex the endophyte seems to be somewhat less uniformly distributed than is usually the case, and a good many cells of the infected area are nearly or quite destitute of the fungus, while in others the hyphae form dense tangled masses or clumps within the cell. No special study was made of the endophyte, as there was no indication that it differs materially from that which has been described in other species. ${ }^{1}$

As usual, the fungus is confined to the older tissues of the gametophyte and does not invade the meristematic tissues, nor the immediate vicinity of the reproductive organs.

The apex of the gametophyte shows a well-marked growing-point (Fig. 3,x). This is slightly inclined towards the dorsal surface of the thallus, the ventral tissue extending somewhat beyond it. In several cases there was evident in median sections a cell (Fig. $4, x$ ), which, from its form and position, closely resembles the apical cell of many liverworts, and probably is the definite simple apical cell of the thallus. No successful horizontal sections of the growing-point could be made, so that the exact form of this apical cell was not determined.

\section{Antheridium.}

As will be seen from the figures, the first antheridia appear very early, and others arise in acropetal succession for a long period. They agree closely with those of the other species in their development

The first division in the mother-cell separates an outer, or cover-cell, from an inner one which gives rise to the mass of spermatocytes (Figs. 7, 8). The cover-cell undergoes a series of divisions by vertical walls, and most of the resultant cells undergo a transverse division, so that the outer wall of the antheridium is composed, for the most part, of two layers of cells; but in one of the cells the transverse wall is suppressed, and this cell (o. in Fig. 9) becomes the operculum, which is destroyed when the antheridium opens and allows the spermatozoids to escape.

The operculum, seen from the surface (Text-fig. 2, B), is nearly square, but occasionally there is a suggestion of the triangular operculum found in Ophioglossum, ${ }^{2}$ a condition also occasionally found in B. obliquum. In the latter species, two opercular cells are not uncommon, and Bruchmann shows

\footnotetext{
${ }^{1}$ See Jeffrey, loc. cit.; Campbell, The Eusporangiatae.

2 Campbell, The Eusporangiatae, Figs. I2, I 3.
} 
three in an antheridium of B. lunaria. It is very likely that more than one may also occur in $B$. simplex, but this was not the case in any of the specimens examined.

The divisions in the inner cell of the young antheridium follow the usual sequence. The first two divisions are at right angles, forming four equal cells, which later divide more or less irregularly until a large number
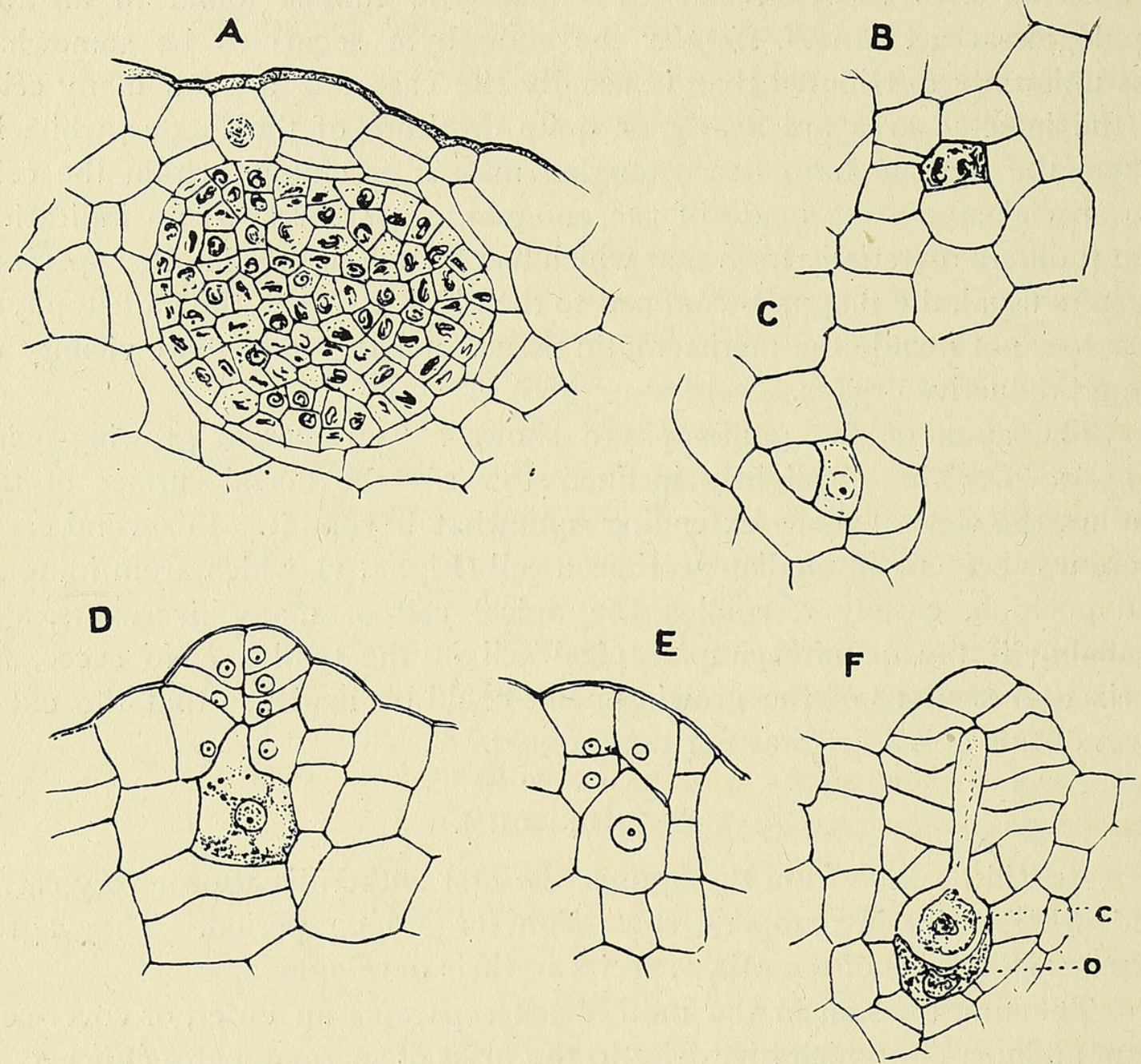

Text-FIG. 2. A. Median section of nearly ripe antheridium. $\times 300 . \quad$ B, C. Surface view of two antheridia showing the operculum. $\times$ 300. D. Median section of archegonium before the separation of the central and neck canal-cells. $\times 300 . \quad$ E. Young archegonium showing irregular division in the cap-cell. F. Archegonium in which the egg-cell, $o$, is much compressed, and the lower part of the canal-cell, c, is enlarged so as to resemble an egg-cell.

of polyhedral cells result-the spermatocytes. So far' as could be determined from a somewhat cursory study, the spermatogenesis does not differ from that of B. virginianum and Ophioglossum. ${ }^{1}$ We may safely assume that the greater part of the spermatozoid is derived from the nucleus of the spermatocyte, while the anterior cilia-bearing portion arises from the blepharoplast.

Of course it was not possible to examine living spermatozoids; but

1 Campbell, The Eusporangiatae. 
not infrequently, in sections, recently opened antheridia were encountered within which were found free spermatozoids. These showed quite satisfactorily the form of the complete spermatozoid (Fig. IO). It is a rather thick, somewhat flattened band, consisting of about two coils, the larger posterior one containing most of the nuclear substance ; the smaller anterior coil is made up mainly of the blepharoplast, to which are attached the cilia. Except for their somewhat smaller size they closely resemble those of B. obliquim. The antheridia are also somewhat smaller than those of the latter species, but, to judge from Bruchmann's figures, are larger than those of $B$. lunaria, and this is true also of the spermatozoids.

\section{The Archegonium.}

The archegonium of $B$. simplex differs but little from that of the other species. As already mentioned, they are situated on the dorsal surface of the thallus, on either side of the antheridial ridge, but are not developed upon the ridge itself (Figs. I, 2). In their earliest stages (Fig. II) they are hardly distinguishable from young antheridia, but very soon their real nature becomes apparent. As in all the Ophioglossaceae, a basal cell is usually absent. The central cell becomes convex above and.grows out into a slender prominence which extends between the elongating neck-cells (Fig. 12; Text-fig. 2, D), and later is cut off to form the elongated neck canal-cell (Figs. I3, 14). The separation of the central cell and neck canal-cell takes place somewhat earlier in $B$. simplex than it does in B. obliquum.

The nucleus of the canal-cell divides into two, one remaining in the broad basal portion, the other being near the apex (Fig. I4). In no cases was there any division wall seen between the two nuclei.

As in all the other Ophioglossaceae, the presence of a ventral canalcell, such as usually is found in the ferns, is difficult to demonstrate. In several instances there was present in the central cell of the mature archegonium a small body, apparently a second nucleus (Fig. I5, v). This nucleus, if such it was, did not stain as strongly as the egg nucleus, nor was there any conclusive evidence that it was the result of a division of the nucleus of the central cell. A similar condition was seen by the writer in other Ophioglossaceae, but it must, for the present, remain an open question whether this nucleus (?) represents the ventral canal-cell usually found in the fern archegonium.

Each of the four primary neck-cells divides, by successive transverse walls, into about six to eight cells, of which about half extend above the surface of the thallus (Fig. 14). Sometimes, apparently the result of the obliquity of one of the first divisions in the cover-cell of the young archegonium, there is a certain lack of symmetry evident (see Fig. I3; Text-fig. 2, $e$ ). 


\section{The EMbryo.}

The genus Botrychium shows a remarkable diversity in the structure of the embryo and young sporophyte, and the writer has recently had occasion to call attention to this. While in B.obliquum and B. virginianum the cotyledon is remarkably well developed, in $B$. lunaria the cotyledon is reduced to an insignificant rudiment, and several more subterranean leaf rudiments are formed before the first foliage leaf appears above ground. $B$. obliquum differs from the other known species in the presence of a conspicuous suspensor, discovered by Lyon. ${ }^{1} \quad$ The embryo of $B$. simplex, as might be expected, more nearly resembles that of $B$. lunaria, to which

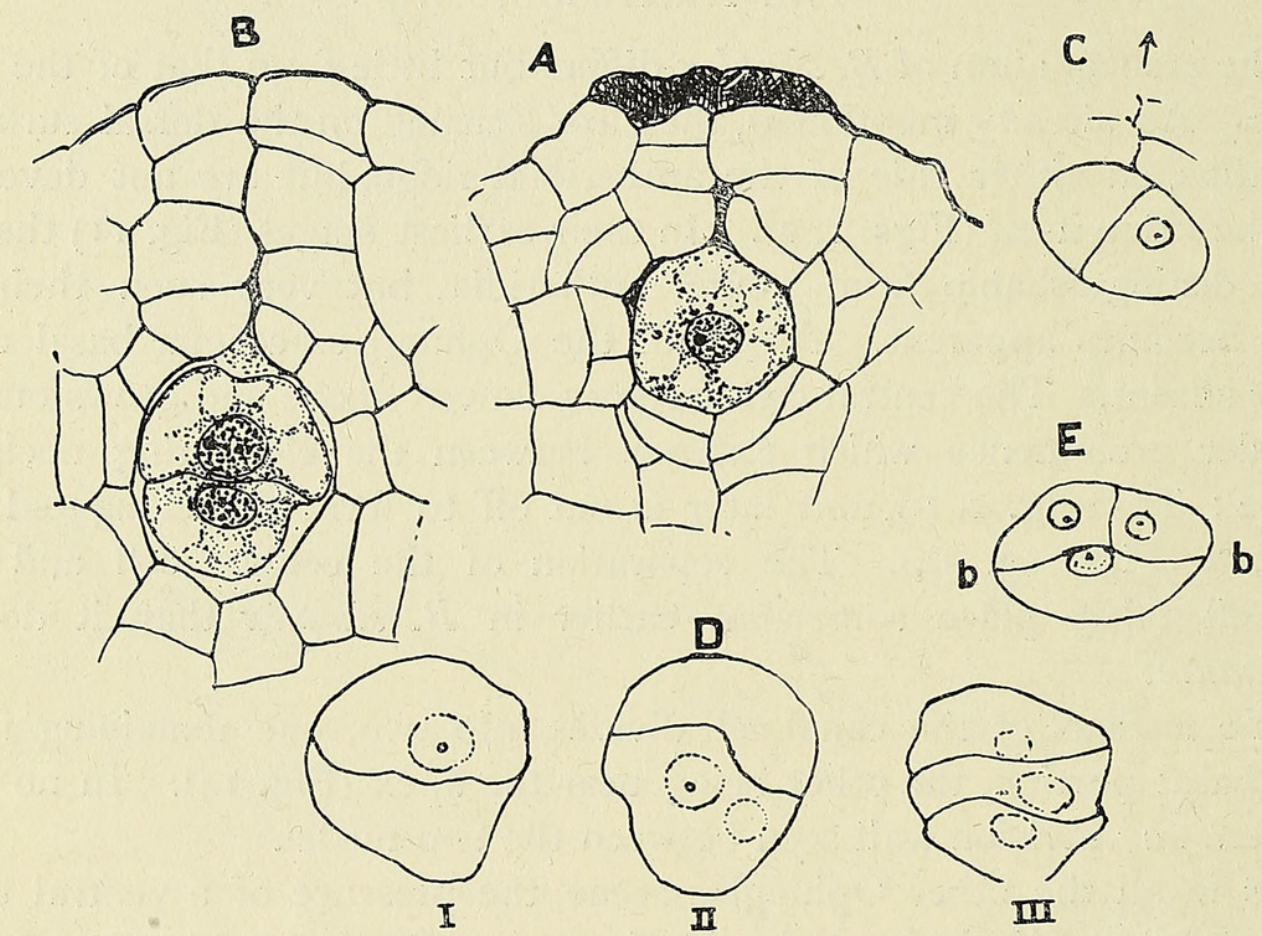

TeXT-FIG. 3. A. Fertilized archegonium containing a unicellular embryo. $\times 300$. в. Twocelled embryo. $\times 300$. C. Two-celled embryo showing oblique basal wall. $\times 300$, D. Three longitudinal sections of a four-celled embryo showing no vertical divisions. $\times 300$. E. Longitudinal section of three-celled embryo. $\times 300$.

it is undoubtedly pretty closely related, than it does either B. obliquum or $B$. virginianum. However, there are differences, especially the much better developed cotyledon, which distinguish it from B. lunaria. How constant these differences are must remain for the present somewhat uncertain. - As in B. lunaria, the embryo may begin to develop while the gametophyte is extremely small, and often several archegonia are fertilized at about the same time, and begin to develop the embryos. As a rule at least, only one embryo develops beyond the earliest stages, and reaches maturity. Unicellular and two-celled embryos were frequently encountered, but the later stages were very much less common.

1 Lyon, H. C.: A New Genus of Ophioglossaceae. Bot. Gazette, xl, I905. 
Bruchmann figures several cases in B. lunaria where two young sporophytes were developed from the same gametophyte; but no such cases were seen in $B$. simplex, although of course it is quite likely that this might sometimes occur.

After fertilization, the free portion of the archegonium neck usually breaks down. The fertilized egg develops a membrane and the unicellular embryo soon completely fills the cavity of the venter (Text-fig. 3, A). It soon divides by a transverse wall, the two cells usually being of approximately equal size, but sometimes one is longer than the other (Textfig. 3, B).

To judge from a not very complete series of embryos secured by the writer, $B$. simplex shows an unusual amount of variation in the early division of the embryo. While the first (basal) wall is generally transverse, as it is in most Eusporangiatae, it may be strongly oblique (Text-fig. 3, C), and the succeeding divisions are extremely variable.

In form, the young embryo may be globular or somewhat elongated either vertically or horizontally (see Text-fig. 3). The succeeding divisions evidently are extremely variable, but the number of young embryos available was too small to make it possible to determine what is the most common arrangement of the cells in the very
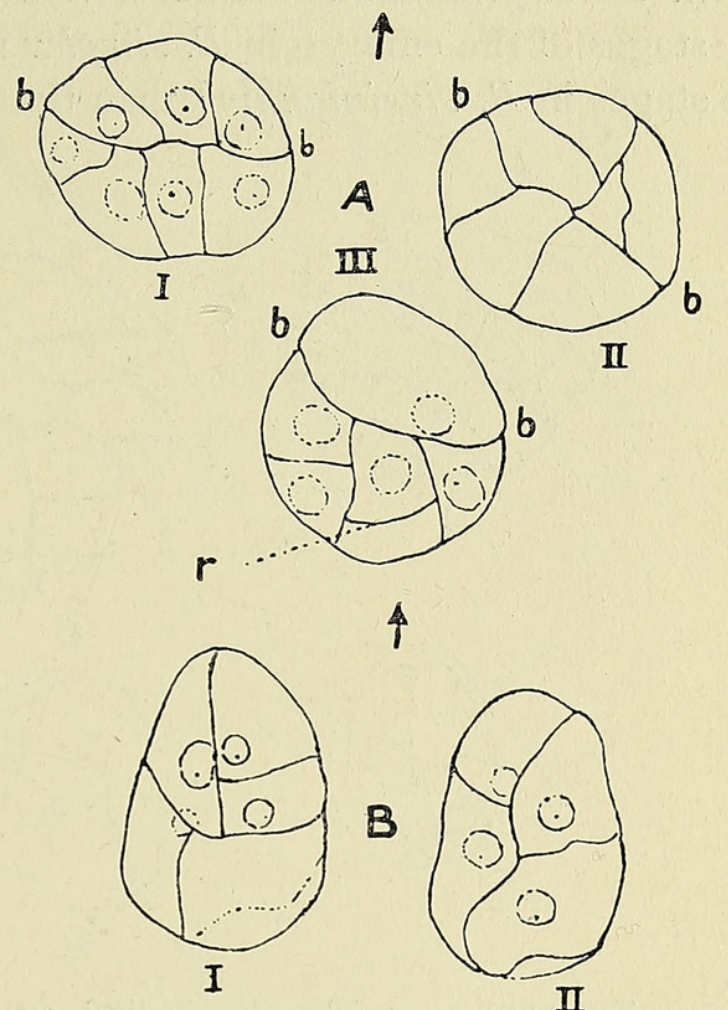

Text-Fig. 4. A. Three longitudinal divisions of a young embryo showing a pretty regular quadrant division; $b, b$, basal wall; $r$, root-initial (?). $\quad \times 300 . \quad$ B. Two somewhat oblique sections of an embryo of about ten cells. $\times 300$.

young embryo. Bruchmann shows a regular quadrant and octant division for B. lunaria, but none of the embryos of $B$. simplex showed such regularity in the position of the walls of corresponding stages.

Text-figs. 3, D, E, show two of the youngest embryos seen by the writer. $\mathrm{E}$ is a three-celled stage, in which the epibasal portion is divided by a median (quadrant) wall, the hypobasal part being still undivided. D shows three longitudinal sections of a four-celled embryo, in which no vertical walls have yet been formed.

Text-fig. 4, A, shows three sections of an older stage in which there is an approach to a quadrant division, and this embryo corresponds pretty closely with that of B. lunaria shown in Bruchmann's Fig. 39. It is not possible to determine at this stage the relation which these early divisions 
bear to the organs of the young sporophyte. It is possible that $r$ in section III may be the beginning of the primary root, but this is by no means certain.

Text-fig. 4, B, shows two somewhat oblique longitudinal sections of an embryo with about ten cells. This embryo was decidedly elongated vertically instead of having the globular form of the embryo shown in A. It was somewhat pointed above, a condition which is sometimes found also in $B$. virginiamum. Indeed, it may be said that in general the earliest stages of the embryo in $B$. simplex resemble more nearly the corresponding stages in $B$. virginianum ${ }^{1}$ than those of $B$. lunaria.
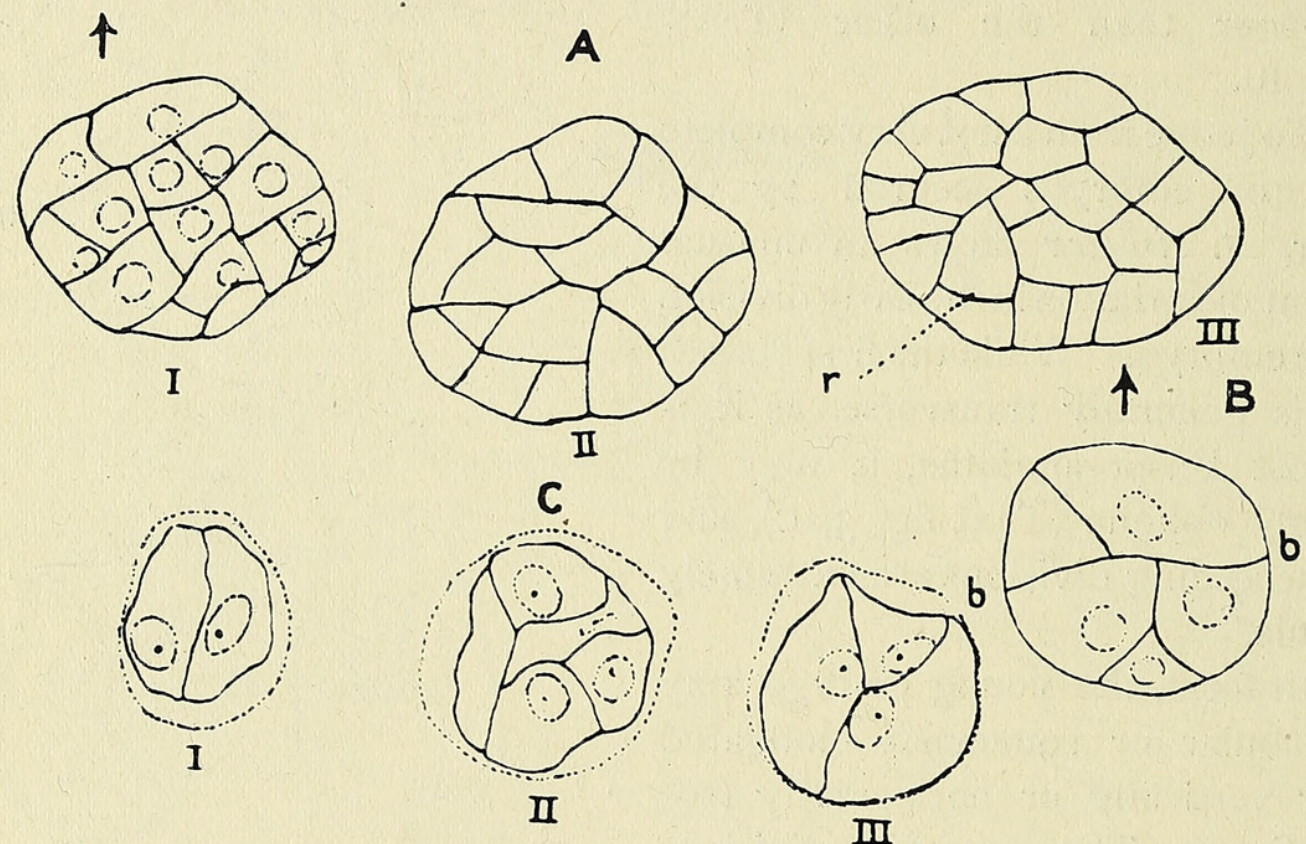

TEXT-FIG. 5. A. Three longitudinal sections of an embryo in which the basal wall is no longer certainly visible. The cell $r$, in III, may be the root-initial. $\times 300$. B. Young embryo showing the basal wall, $b$, clearly. C. Three transverse sections of a young embryo; $I$, section next the archegonium. $\times 300$.

A young embryo of seven cells (Text-fig. 4, B) had two cells in the epibasal portion and five in the hypobasal, the latter quite irregularly disposed. The resemblance to $B$. virginianum is also shown by a comparison of the transverse sections. Text-fig. 5, C, shows such a series, and it is much like a similar series of B. virginianum, shown in Fig. $3^{I}$ of the writer's monograph of the Eusporangiatae. In both cases the section next the archegonium was composed of two equal cells, showing an absence of octant walls in the epibasal region.

In a somewhat older stage (Text-fig. $5, \mathrm{~A}$ ) there is a large cell, $r$, in the hypobasal region which in form and position suggests that it may be the initial of the primary root; but as no stages were found between this and the very much older embryo shown in Text-fig. 6 , in which the apical cell of the root was plainly visible, this is by no means certain. 
Bruchmann's figures of such intermediate stages in B. lunaria do not show any evident root-initial, which is first shown in much older embryos. In corresponding stages of both $B$. obliquum and $B$. virginianum the writer has found the initial cell of the primary root to be readily demonstrable. In the former species, however, the initial cell is developed later than in $B$. virginianum, and originates near the centre of the embryo, very much as in the Marattiaceae and Ophioglossum. In B. virginiamum the root-initial is cut off from a superficial cell, much as in the leptosporangiate ferns. It is, in fact, very much like the cell $r$ shown in Text-fig. 5 .

The large embryo shown in Text-fig. 6 appears to be somewhat younger than Bruchmann's Fig. 42, but it shows decidedly more differentiation of the parts than Bruchmann's figures of $B$. lunaria exhibit. In the latter, apparently the only sign of differentiation in the embryo at this time is the presence in the axis of what looks like the beginning of a strand of procambium. The apex of the root seems to be quite undifferentiated.

In $B$. simplex, at this stage, the apical cell of the

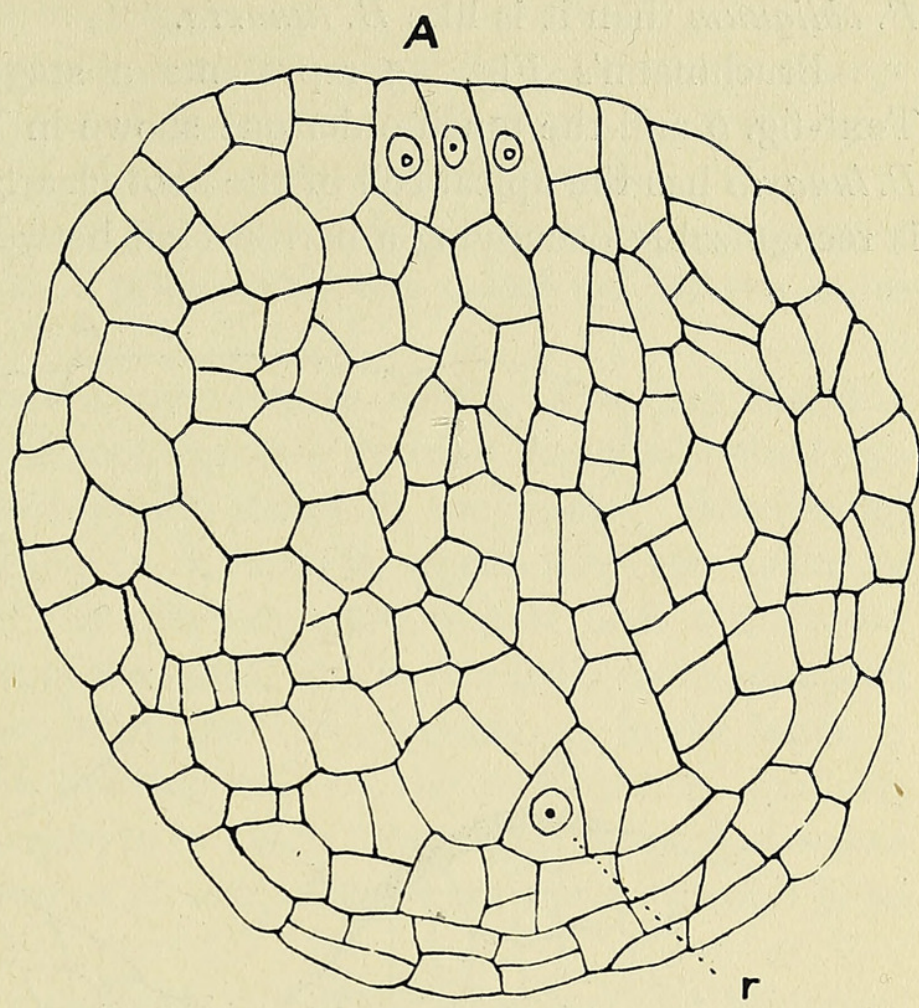

B

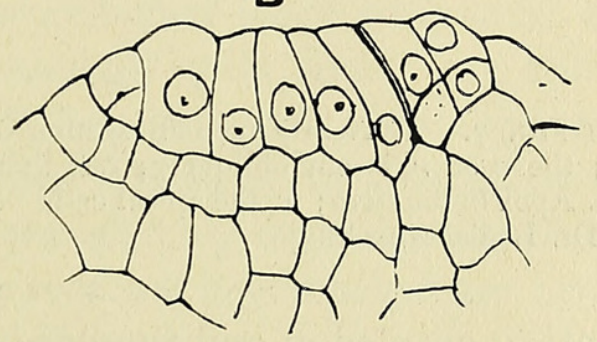

TEXT-FIG. 6. A. Nearly median section of a large embryo showing the initial of the root, $r$, and the apical meristem. $\times 300$. B. The apical meristem from another section of the same embryo. root, $r$, is clearly evident, and the apex of the embryo is occupied by a group of columnar meristem cells, one of which is probably the initial for the stem-apex, and possibly one may represent the apex of the cotyledon; but it is not possible to be sure of this. There is a slight indication of the formation of an axial procambium strand, but, unlike $B$. lunaria and $B$. virginianum, the foot, as such, is not clearly delimited, and the embryo at this stage suggests the bipolar embryo of B.obliquum.

The writer was unable to secure any stages between this embryo and 
the very much older one shown in Text-fig. 7 , in which the root had emerged from the gametophyte and the stem-apex and cotyledon were already well developed. It is, however, clear that the differentiation of the primary root and stem-apex occur much earlier in $B$. simplex than in $B$. lunaria, and in this respect $B$. simplex is more like $B$. virginianum or $B$. obliquum than it is like B. lunaria.

Bruchmann's Fig. 43 represents a stage intermediate between our Text-fig. 6 and the much older one shown in Text-fig. 7. This embryo of B. lunaria has the apical cell of the root clearly defined, and the stem-apex is recognizable, occupying a narrow cleft between the base of the extremely

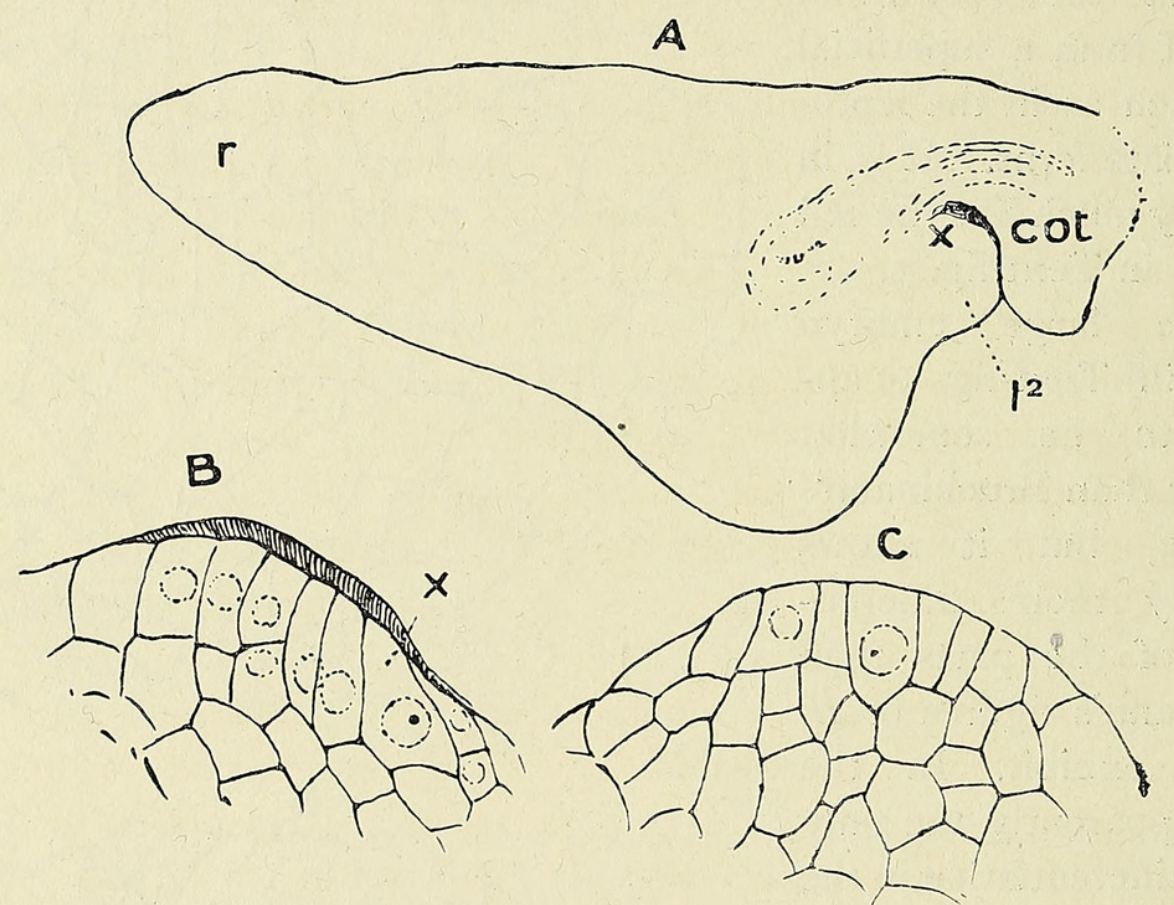

TEXT-FIG. 7. A. Nearly median section of a young sporophyte, in which the root has just emerged; the root, $r$, is cut obliquely; cot, the cotyledon; $x$, apex of the stem; $l^{2}$, second leaf. $\times 45$. B. Apex of the stem; $x$, the apical cell. $\times 300$. C. Apex of second leaf. $\times 300$. Sections made by Dr. L. Baas-Becking.

rudimentary cotyledon and the base of the massive root. At this stage the embryo consists almost entirely of the root and foot.

$B$. simplex differs notably from $B$. lunaria in the earlier appearance of the stem-apex and cotyledon, and the much better development of the latter. The fully developed cotyledon was not seen by the writer, but Dr. L. Baas-Becking, who has been engaged in a study of the more advanced stages of the young sporophyte, has informed him that the cotyledon, though much less conspicuous than that of either B. obliquum or $B$. virginianum, develops a small lamina and is apparently functional.

Text-fig. 7 shows a young sporophyte slightly older than that represented by Bruchmann's Fig. 45. The general relation of the parts is much the same, but the foot is less prominent in $B$. simplex, and the cotyledon and 
stem-apex relatively much more important. The cotyledon is very much like that of $B$. obliquum at a similar stage of development, showing a very large basal sheath which encloses the stem-apex and the young second leaf. The upper part of the leaf, however, is less developed than in B. obliqunm. It strikingly resembles the early stages of the leaves of the older sporophyte shown by Bruchmann in his Fig. 57 .

The stem-apex of the young sporophyte (Text-fig. $7, B$ ) shows a large apical cell, which differs from that of $B$.lunaria in having a truncate base. It thus closely resembles that of $B$. obliquum or Ophioglossum.

The second leaf (Text-fig. 7 , C) forms a blunt cone, whose summit is occupied by a single large cell, presumably the apical cell of the more advanced leaf.

The primary vascular bundle is now clearly visible, extending from the cotyledon into the root. As the root makes a decided angle with the cotyledon, only the base of the root-bundle shows in the figure. Bruchmann shows exactly the same condition in B. lunaria, where, however, owing to the very rudimentary nature of the cotyledon, the bundle does not extend into it. While the development of the apical bud is decidedly more advanced in B. simplex than in B. lunaria, its further development, as in the latter, is slow when compared with the development of the root-system, and the general type of the young sporophyte is much more like that of $B$. lunaria than like that of $B$. virginianum or $B$. obliquum, where the cotyledon is so conspicuous.

In $B$. simplex, while the cotyledon is still small, a second root develops, and soon after a third, while the apical bud remains quite inconspicuous (Fig. 16). This young sporophyte showed two large roots and a third smaller one, while the terminal bud, although quite smail, was still more conspicuous than in similar stages of B. lunaria. The gametophyte $(p r$. can still be seen. As will be seen from a section of this plant (Textfig. $8, \mathrm{~A}$ ), the cotyledon and stem-apex are scarcely more developed than at the time of the emergence of the primary root, but nevertheless are decidedly more so than in corresponding stages of B. lunaria.

The steles of the three roots unite near the centre of the sporophyte, where they are joined by the bundle from the cotyledon; but there is no stelar tissue belonging to the stem-apex. Near the junction of the cotyledonary bundle and that of the third root can be seen a group of tracheides which can be seen to connect also with the base of the second root. By examining a series of sections, this tracheary tissue can be found to merge with the xylem of the primary root, and forms a solid strand of xylem in the centre of the axis of the young sporophyte.

Near the base of the primary root (Text-fig. 9, D) two very unequal xylems appear, but nearer the apex of the root the smaller one disappears and the bundle becomes monarch. 

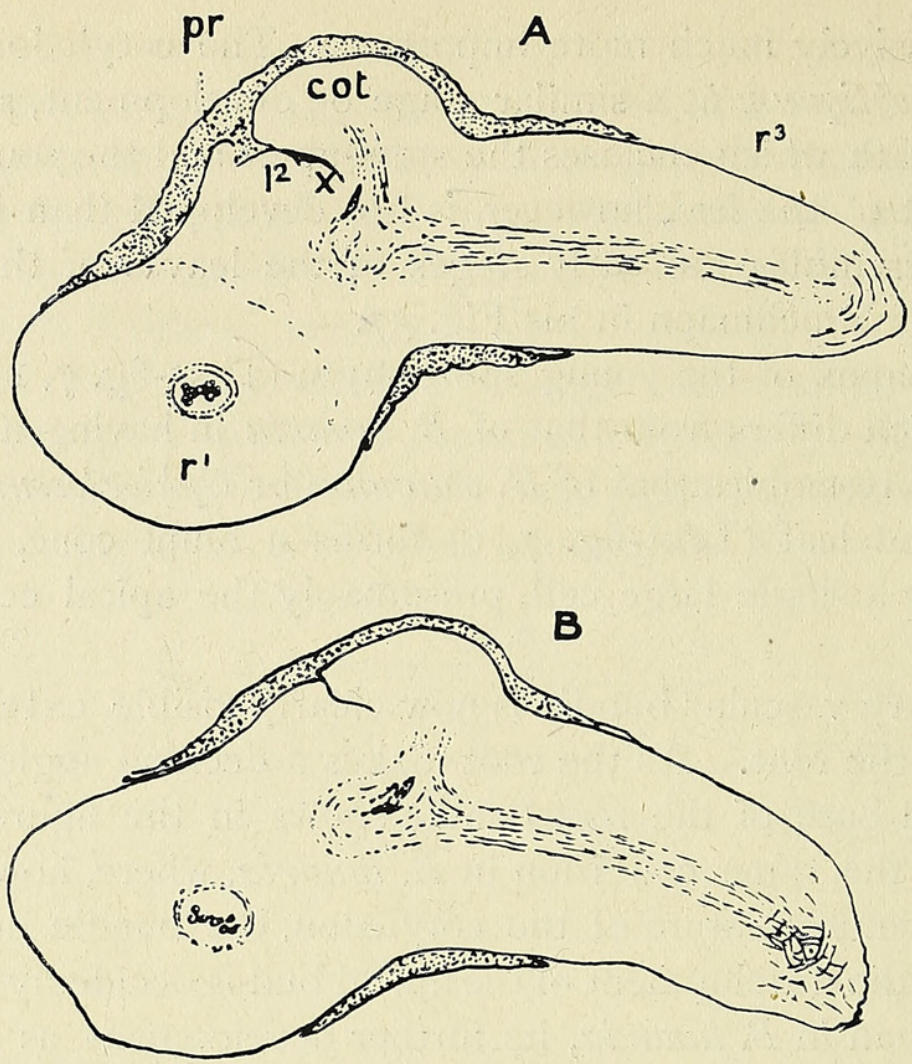

TeXT-FIG. 8. Two sections of the sporophyte shown in Plate XVI, Fig. I6. pr, gametophyte; $r^{1}, r^{2}, r^{3}$, the three roots; cot, cotyledon; $l^{2}$, second leaf; $x$, stem-apex. $\times 40$.

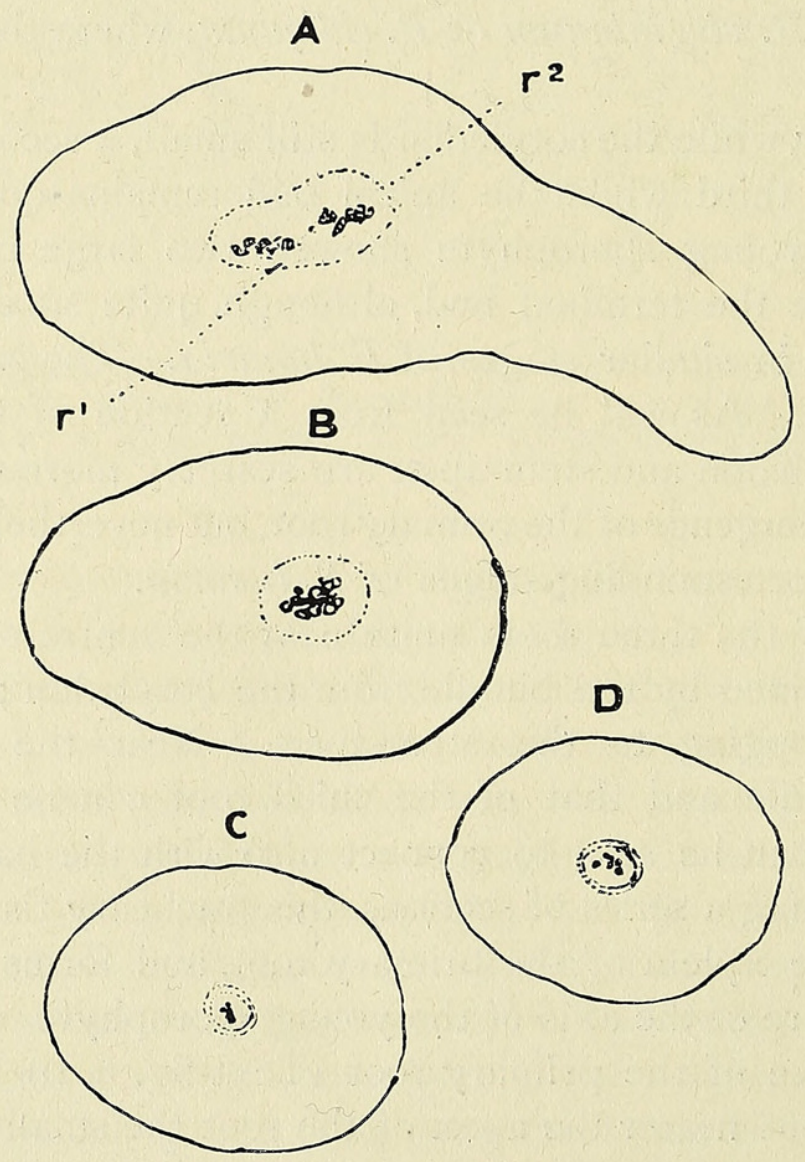

TEXT-FIG. 9. A, Another section of the same sporophyte as in Text-fig. 8, showing the approximation of the xylems from the first and second roots. $\times 40$. B. Another section showing the complete fusion of the xylems. C. Section of the first root showing single xylem. D. The same near the base, showing two very unequal xylems. 
The second root of this plant (Text-fig. IO, B) was diarch, but the two groups of tracheides were unequal in size.

The apex of the third root (Text-fig. Io, A) shows the characteristic tetrahedral initial cell, with somewhat irregular segmentation. The rootcap is derived in part from direct segments cut off from the apical cell, and in part from periclinal divisions in the lateral segments.

The cotyledon probably emerges after about four roots have developed, and soon after, perhaps the next year, the second leaf appears above ground as a very small fertile frond (Figs. I7, 18, 19). The base of the petiole forms an elongated sheath, within which can be plainly seen the next
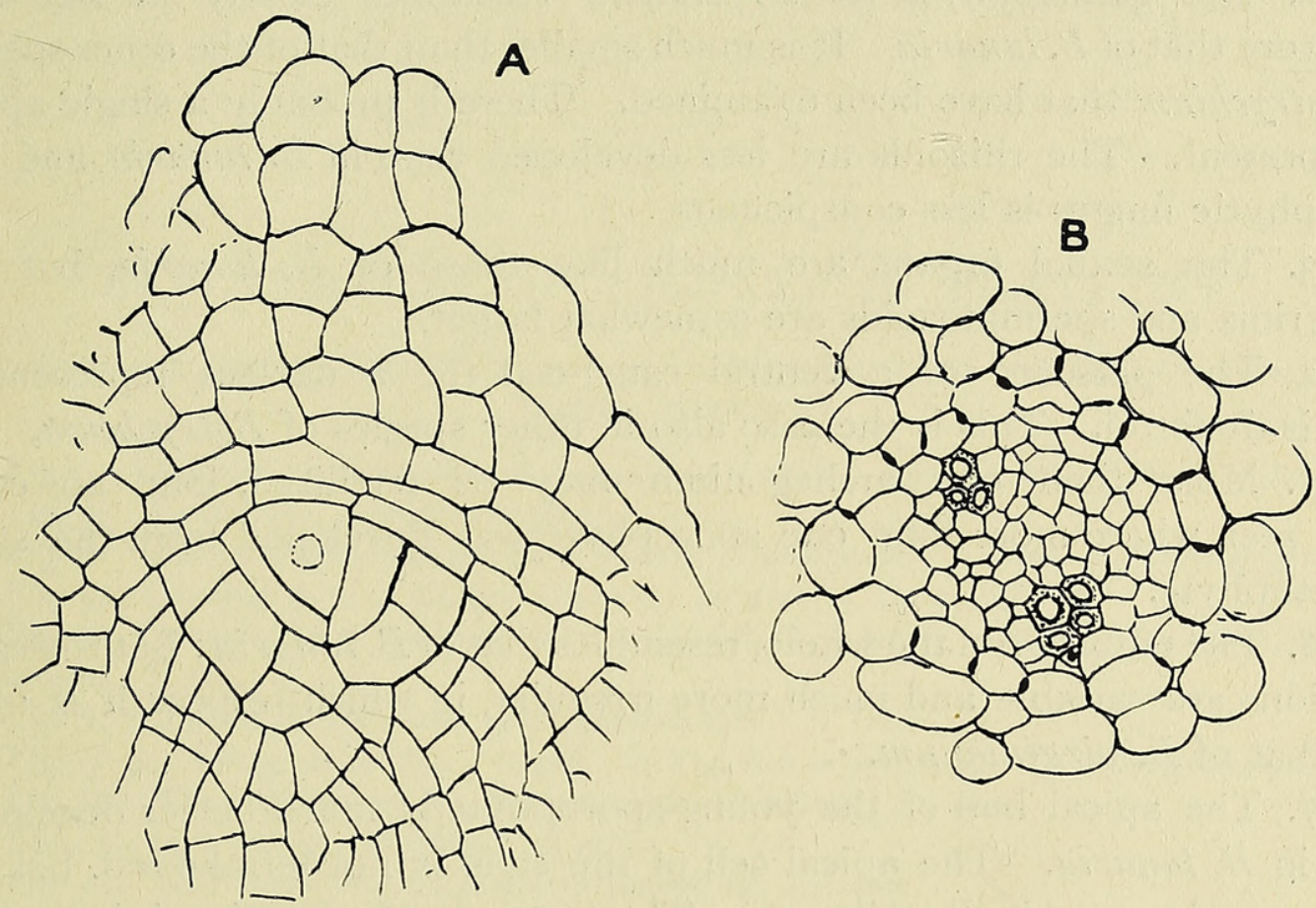

TexT-FIG. IO. A. Median section of the apex of the third root. $\times 300 . \quad$ B. Cross-section of the bundle of the second root. $\times 300$.

younger leaf. The lamina of the leaf is very small, with a slightly toothed margin and dichotomous venation. The sporangiophore is incurved and bears a very few sporangia. The one shown in Fig. I 8 had only one perfect sporangium, and it may be that sometimes no perfect sporangia develop on this rudimentary sporophyll.

The relation of the sterile lamina and the sporangiophore was not investigated, but it is highly probable that the two arise by an early dichotomy of the leaf-apex, such as Bruchmann found to be the case in the later leaves in B. lunaria.

While the embryo of $B$. simplex agrees in the main with that of $B$. lunaria, the subordination of the foliar structures to the roots of the young sporophyte is much less marked. In B. lunaria Bruchmann states that at least seven, and sometimes as many as nine, rudimentary leaves are 
formed, which never appear above ground, before the first functional leafa sporophyll-is developed. ${ }^{1}$ He believes that only one leaf-even the rudimentary ones-is formed each year, but this seems rather unlikely.

As in $B$. simplex, it appears that in B. lunaria there is no cauline stele, but all the stelar tissues belong to the roots, or to the rudimentary traces of the early leaves.

\section{SumMARY AND CONCLUSION.}

I. Botrychium simplex, the smallest species of the genus, is undoubtedly nearly related to $B$. lunaria, but is specifically distinct.

2. The gametophyte of $B$. simplex resembles closely in size and structure that of B.lunaria. It is much smaller than that of the other species of Botrychium that have been examined. There is probably a single apical cell present. The rhizoids are less developed than in B. lunaria and the endophytic fungus is less conspicuous.

3. The sexual organs are much like those of $B$. lmaria, but the antheridia and spermatozoids are somewhat larger.

4. The presence of a ventral canal-cell (or a nucleus representing this) is doubtful. This is the case also in other species of Botrychium.

5. More than one archegonium may be fertilized, but no cases were seen where more than one sporophyte was developed from the same gametophyte.

6. The embryo, on the whole, resembles that of B. lunaria; but the early divisions are variable and much more irregular, in which respect it is more like that of $B$. virginianum.

7. The apical bud of the young sporophyte is much better developed than in B. lunaria. The apical cell of the stem is not tetrahedral, but has a truncate base, as in $B$. obliquum. The cotyledon is functional, but much smaller than that of $B$. obliquum or $B$. virginianum. The second leaf is a sporophyll.

8. The root-system develops much more rapidly than the apical bud, but does not preponderate so much as in B. lunaria. The roots are of the ordinary type, with a tetrahedral apical cell. The first root may be monarch; the succeeding roots are diarch.

9. The vascular skeleton of the young sporophyte is made up exclusively of the steles belonging to the roots and leaves.

In spite of the much less regular divisions in the young embryo, $B$. simplex agrees pretty closely with $B$. lunaria. These members of the section Eubotrychium have a much smaller gametophyte than the other species that have been studied, and the young sporophyte is characterized by the preponderant development of the root-system compared with the foliar structures. 
Dr. Baas-Becking, who has been engaged recently in a study of the later stages of the young sporophyte, finds that $B$. simplex shows some differences in the development of the early leaves, the cotyledon varying somewhat in its development, but never being so reduced as in B. lunaria, and there is never such a series of rudimentary leaves as Bruchmann describes for that species. Dr. Baas-Becking suggests that possibly the long subterranean existence of $B$. lunaria in Europe may be due to less favourable conditions than those under which the specimens of $B$. simplex were found in Minnesota. It would be interesting to know how $B$. lunaria in the northern United States and Canada compares in this respect with the European specimens studied by Bruchmann.

\section{EXPLANATION OF FIGURES IN PLATE XVI.}

\section{Illustrating Professor Campbell's paper on the Gametophyte and Embryo of Botrychium simplex, Hitchcock.}

Fig I. Very young gametophyte of Botrychium simplex. $\times 5$ o. $\quad$ t, antheridia; $ᄋ$ archegonia. Fig. 2. A somewhat older gametophyte. $\times 3^{2}$.

Fig. 3. Median longitudinal section of a small gametophyte. $\times$ roo. $x$, growing-point.

Fig. 4. Growing-point of the gametophyte. $\times 400 . \quad x$, the apical cell.

Fig. 5. Cross-section of the gametophyte, showing the relative position of the antheridia and archegonia. $\times 100$.

Fig. 6. Cross-section of a very small gametophyte. $\times$ Io0.

Figs. 7-9. Young antheridia. $\times 400$. In Fig. $8, x$ is the apical cell of the gametophyte.

Fig. 10. Three spermatozoids, from an open antheridium. $\times 900$.

Figs. II-I3. Young archegonia. $\times 400$.

Fig. I 4. Median section of a mature archegonium. $\times{ }_{4} 00$.

Fig. I 5. Venter of a mature archegonium, showing a second nucleus(?), $v$, perhaps representing a ventral canal-cell ; c, lower part of neck canal-cell. $\times$ about 600 .

Fig. I6. Two views of a gametophyte with young sporophyte attached. $\times 5$.

Fig. 17. An older sporophyte, still attached to gametophyte, $p r . \times 3$.

Fig. I8. $a$, second leaf with rudimentary sporangiophore. $\times 3 . b$, sporangiophore. $\times$ io.

Fig. 19. Second leaf with relatively well developed sporangiophore. $x$ about 10 . 
Annals of Botany,
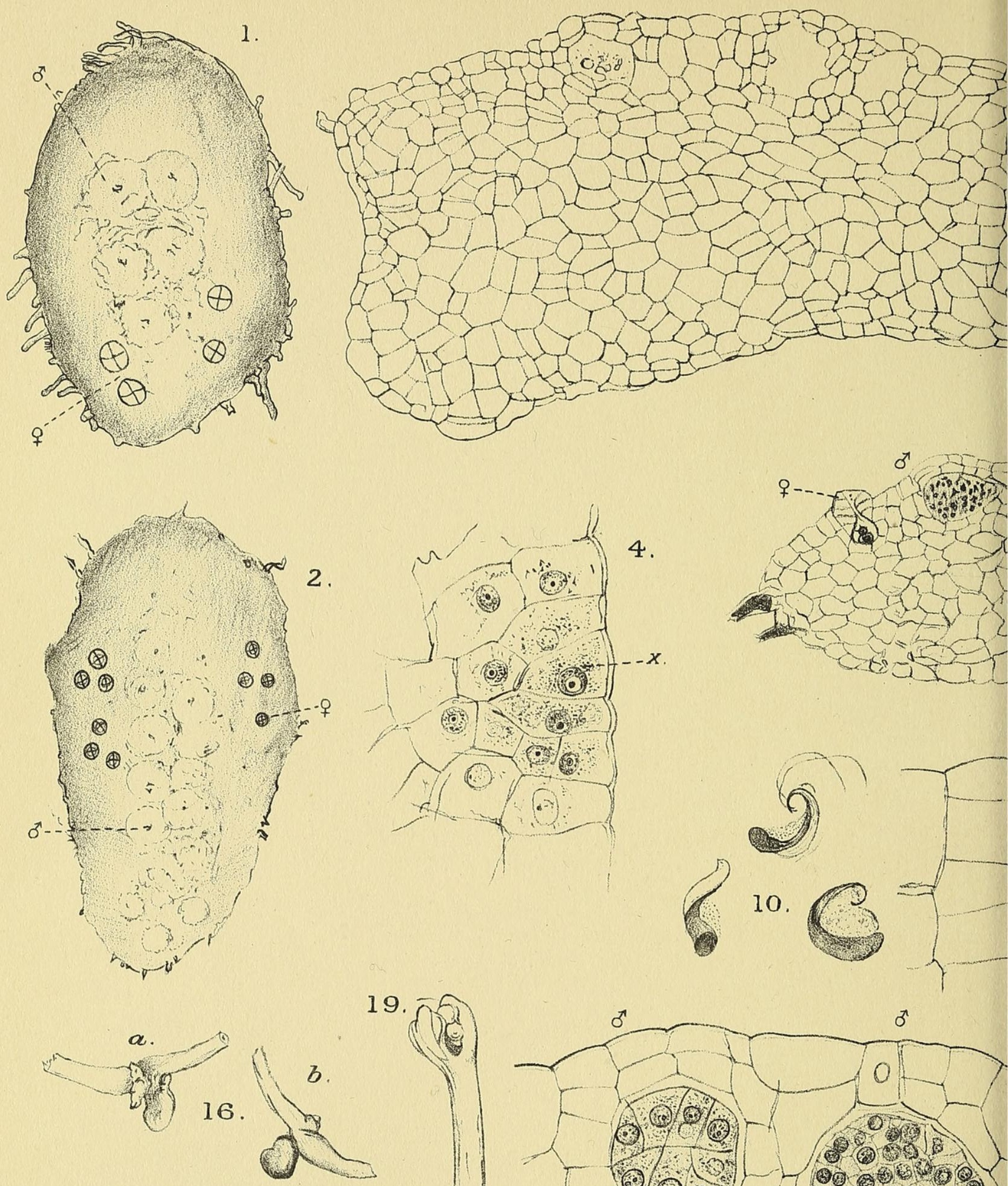

19.
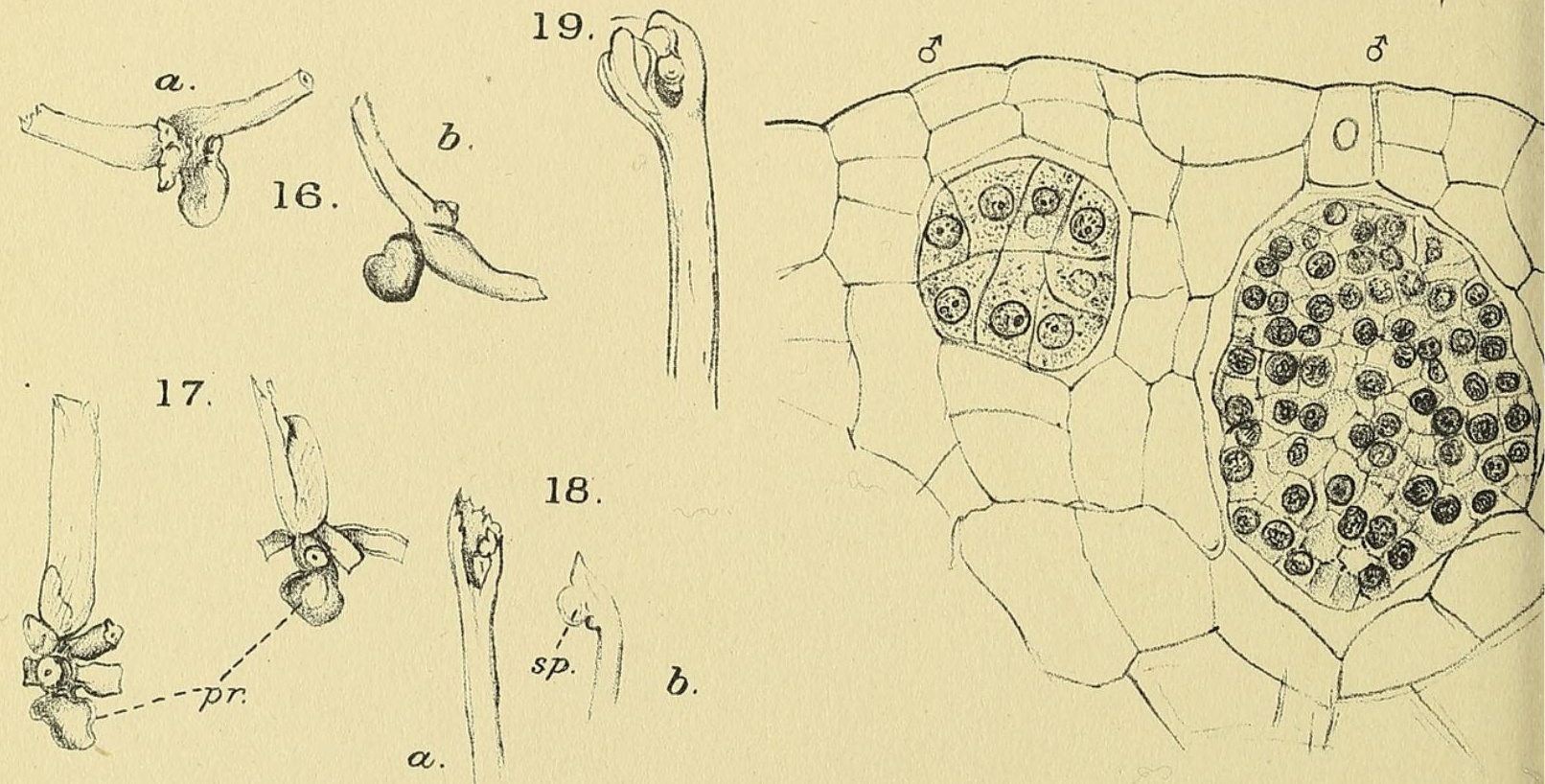

D.H.Campbell del 


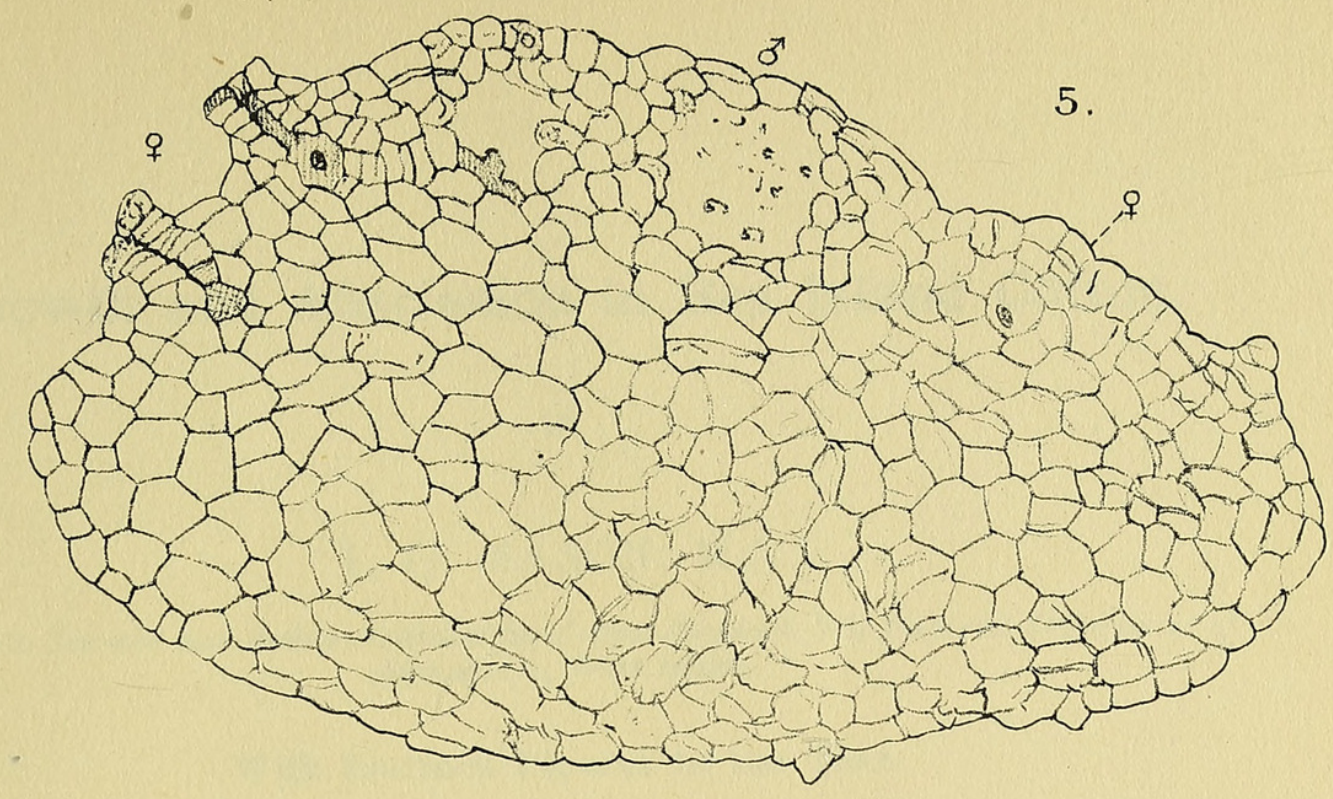

6.

7.

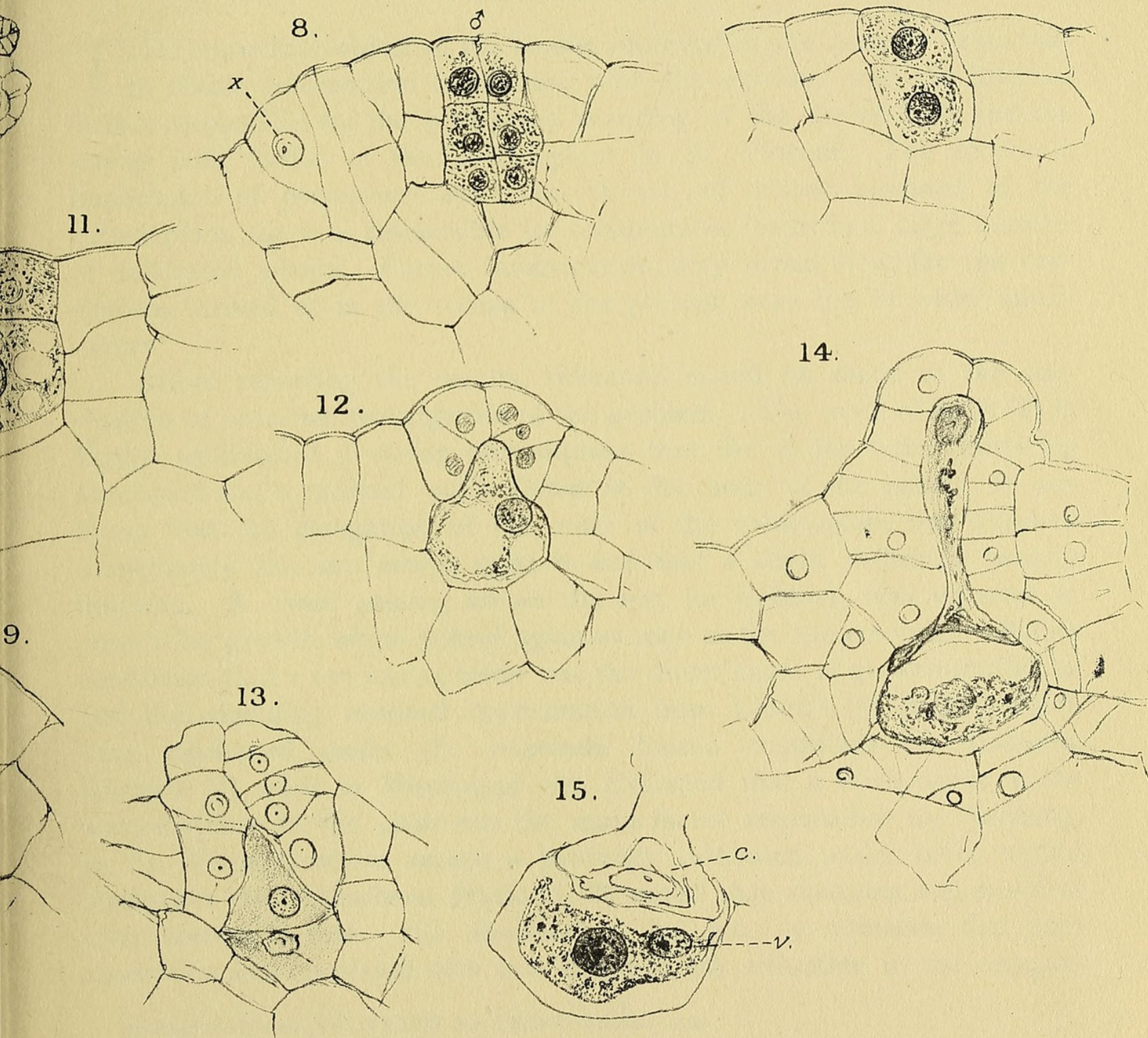



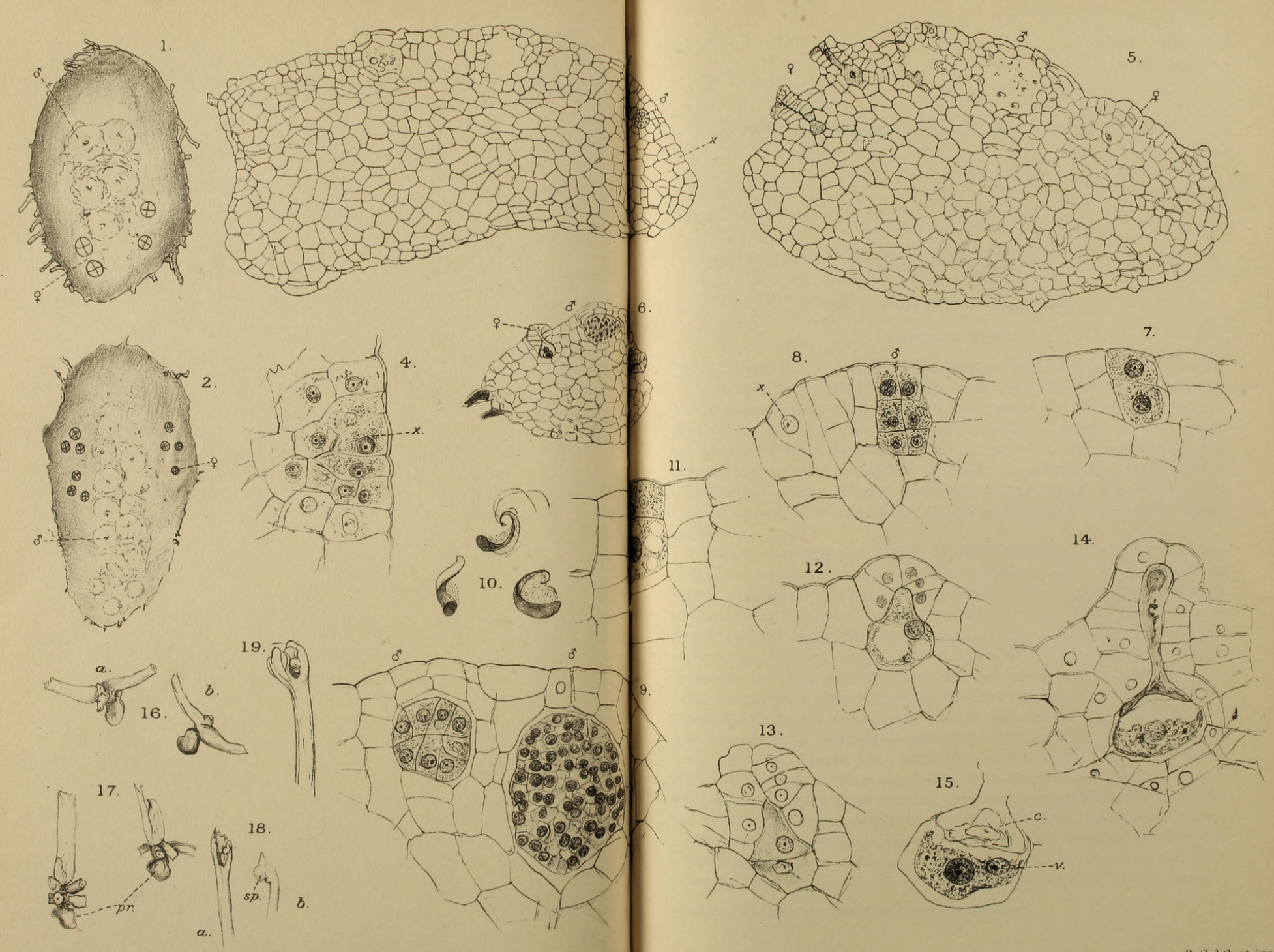

D.H.Campbell de] 


\section{$2 \mathrm{BHL}$ Biodiversity Heritage Library}

Campbell, Douglas Houghton. 1922. "The gametophyte and embryo of Botrychium simplex, Hitchcock." Annals of botany 36, 441-455. https://doi.org/10.1093/oxfordjournals.aob.a089816.

View This Item Online: https://www.biodiversitylibrary.org/item/234428

DOI: https://doi.org/10.1093/oxfordjournals.aob.a089816

Permalink: https://www.biodiversitylibrary.org/partpdf/319053

\section{Holding Institution}

Smithsonian Libraries

\section{Sponsored by}

Biodiversity Heritage Library

\section{Copyright \& Reuse}

Copyright Status: Not in copyright. The BHL knows of no copyright restrictions on this item.

This document was created from content at the Biodiversity Heritage Library, the world's largest open access digital library for biodiversity literature and archives. Visit BHL at https://www.biodiversitylibrary.org. 